\title{
Immunoreactive Insulin, Suppressible, and Non Suppressible Insulinlike Activities in Rats after Administration of Glucose and Induction of Hyperglycaemia by Mannoheptulose
}

\author{
E.R. Fromsch, A. JAKob, G.R. ZaHND and E. Simon
}

\begin{abstract}
Metabolic Unit, Department of Medicine, University of Zurich*, Research Laboratory, Medical Outpatient Department, University of Geneva** and Biodynamics Institute, Weizmann Institute of Science, Rehovoth, Israel***

Received July 22, 1966
\end{abstract}

Summary. 1. Blood glucose, immunoreactive, insulin suppressible and non-suppressible insulin-like activities were determined in rats after the administration of glucose and D-mannoheptulose respectively. The latter caused a marked rise of the blood sugar concentration There was a correlation between blood sugar and suppressible insulin-like activity in all groups of rats except those injected with mannoheptulose. The results support the concept that mannoheptulose acts by inhibiting the release of insulin from the $\beta$-cells of the islets. -2 . Immunoreactive insulin roughly paralleled suppressible ILA, but the quantitative correlation between the two was not satis. factory. - 3. Nonsuppressible ILA was approximately the same in all groups of rats. Changes in the level of suppressible ILA were not reflected in the concentration of non-suppressible ILA.

Insuline immunoréactive, activités insuliniques suppri. mable et non supprimable chez le rat après administration de glucose et après provocation d' hyperglycémie par manno. heptulose.

Résumé. 1. La glycémie, l'insuline immunoréactive etles activités insuliniques supprimable et non supprimable ont été mesurées chez des rats chez les quels une hyperglycémie avait été provoquée par le glucose ou le D-mannoheptulose. Une corrélation entre la glycémie et l'activité insulinique supprimable a été observée dans tous les groupes de rats à l'exception de ceux traités par le mannoheptulose. Ces résultats confirment l'hypothèse selon laquelle l'action hyperglycémiante du mannoheptulose est due à son pouvoir inhibiteur de la sécrétion d'insuline par les cellules
B des îlots de Langerhans. - 2. Bien que les valeurs des activités insuliniques immunoréactive et supprimable fussent semblables, la corrélation quantitative entre ces deux mesures ne s'est pas avérée satisfaisante. - 3. L'activité insulinique non supprimable est restée la même dans tous les groupes de rats. Les fluctuations de l'activité insulinique supprimable ne se sont pas traduites par des fluctuations de la concentration de l'activité insulinique non supprimable.

Immunoreaktives Insulin, hemmbare und nicht hemmbare insulinähnliche Aktivität bei Ratten nach Gabe von Glucose und durch Mannoheptulose erzeugter Hyperglykämie.

Zusammenfassung. 1. Blutglucose, immunoreaktives Insulin, hemmbare und nicht hernmbare Insulinaktivität (IA) wurden bei Ratten bestimmt, die mit Glucose oder D. Mannoheptulose hyperglykämisch gemacht wurden. Blut. glucose und hemmbare IA korrelierten in allen Gruppen mit Ausnahme der mit Mannoheptulose behandelten Rat. ten. Diese Resultate bestätigen frühere Befunde und Hypothesen, wonach Mannoheptulose die Insulinsekretion der $\beta$-Zellen der Inseln unterdrückt. - 2. Obschon sich immunoreaktives Insulin und hemmbare IA in den verschiedenen Gruppen von Ratten ähnlich verhielten, ergab sich keine gute Korrelation zwischen diesen beiden Größen. - 3. Die Konzentration der nicht hemmbaren IA war in allen Gruppen von Ratten ungefähr gleich. Die Veränderungen der hemmbaren IA spiegelten sich in der Konzentration der nichthemmbaren IA nicht wieder.

\section{Introduction}

The poorly metabolized seven-carbon sugar $\mathrm{D}$. mannoheptulose induces hyperglycaemia and an acute diabetic syndrome in the rat $[11,12]$ and in the rab. bit [3]. The hyperglycaemic response is linearly proportional to the dose [7]. Mannoheptulose inhibits insulin release from slices of rabbit pancreas in vitro [3]. In a concentration of $3 \mathrm{mg} / \mathrm{ml}$, mannoheptulose did not suppress basal insulin release but prevented the $\beta$-islet cell response to increased glucose concentrations.

* Supported by research grants from the Schweizerische Nationalfonds (3854) and from the U.S. Public Health Service (A 5387 ).

** Supported by the Schweizerische Nationalfonds (4042).

*** Supported in part by U.S. Public Health Service research grant AM $05701-03$.
This study was undertaken to verify the inhibitory effects of mannoheptulose on insulin secretion in the rat in vivo [3] and to find out whether or not the changes in the levels of suppressible and immunochemically assayed insulin-like activity (immunoreactive insulin were correlated with corresponding changes of nonsuppressible ILA.

This study also permitted comparison of suppressible with immunoreactive insulin over a wide range of blood sugar levels.

\section{Materials and Methods}

Glucose was determined by the method of RAABO and TerkILDsEN [8]. Suppressible and nonsuppressible ILA were measured by the modified [2] procedure of Fromscr et al. [4]. Pork insulin served as standard ${ }^{1}$.

${ }_{1}$ We would like to thank Dr. H. EGE, Novo, for the preparations of the crystalline pork and rat insulin. 
Immunoreactive insuin was measured by a radio immunoassay making use of the double antibody technic and of rat insulin as standard [15].

Male rats of the Biodynamies Institute colony, raised on a diet of Purina Laboratory chow, were selected for these experiments when they had reached $200 \mathrm{~g}$ of body weight. The rats were divided into three treatment-groups in two series:

Group one was injected s.c. with $2.0 \mathrm{ml}$ saline and sacrificed after 60 minutes. Group two was injected s.c. with $350 \mathrm{mg}(2 \mathrm{ml}, 17.5 \%)$ glucose and sacrificed after 30 minutes. Group four was injected s.c. with $400 \mathrm{mg}$ (2 $\mathrm{ml}, 20 \%$ ) mannoheptulose and sacrificed after 60 minutes.

About six months after these experiments had been performed, colony conditions had changed, necessitating repetition of the experiments. Therefore a second series was performed with the additions of group three in which the animals received $350 \mathrm{mg}(2 \mathrm{ml}$, $17.5 \%$ ) glucose by gavage. They were sacrificed after 30 minutes.

Venous blood samples were periodically drawn from the tail vein for glucose estimations. Finally the rats were anesthesized with $\mathrm{CO}_{2}\left(50 \% \mathrm{CO}_{2} / 50 \% \mathrm{O}_{2}\right)$, to allow blood collection by aorta puncture. The blood

\section{Results}

The results obtained in the second series of 25 rats are shown in Table 1. The venous blood sugar of the rats given glucose s.c. or orally was $40 \mathrm{mg} 100 / \mathrm{ml}$ higher than that of the control group injected with saline. The arterial blood sugars were 20 to $40 \mathrm{mg} / 100 \mathrm{ml}$ higher than the venous blood sugars in group one, two and three indicating considerable glucose uptake by the tissues as well as possible stimulation of glycogenolysis during $\mathrm{CO}_{2}$ anesthesia. Suppressible ILA paralleled the blood sugar in all but the mannoheptulosetreated group. In 4 out of 6 animals injected with mannoheptulose suppressible ILA was below $30 \mu \mathrm{U}$ per $\mathrm{ml}$. Nonsuppressible ILA did not show significant variations from group to group. Figure 1 shows that suppressible ILA was closely correlated with the venous blood sugar level. If the straight line be extrapolated to the abscissa, virtual absence of suppressible ILA would be expected at blood sugar concentrations of $50 \mathrm{mg}$ per $100 \mathrm{ml}$. The two points obtained in the mannoheptulose groups were completely inconsistent with the other results. Although the blood sugar in the mannoheptulose group of the second series was much higher than in the rats treated with glucose,

Table 1. Blood glucose and insulin-like activities in rats treated with saline, glucose and mannoheptulose respectively Experimental conditions as under Materials and Methods. - The means and the SEM are given.

\begin{tabular}{|c|c|c|c|c|c|c|c|c|c|}
\hline \multirow[b]{2}{*}{ Treatment } & \multirow[b]{2}{*}{$\begin{array}{l}\text { I } \\
2 \text { ml } \\
\text { saline } \\
\text { s.c. }\end{array}$} & \multirow[b]{2}{*}{$\begin{array}{l}\text { II } \\
350 \mathrm{mg} \\
\text { glucose } \\
\text { s.c. }\end{array}$} & \multirow[b]{2}{*}{$\begin{array}{l}\text { III } \\
350 \mathrm{mg} . \\
\text { glucose } \\
\text { p.o. }\end{array}$} & \multirow[b]{2}{*}{$\begin{array}{l}\text { IV } \\
400 \mathrm{mg} \\
\text { manno- } \\
\text { heptulose } \\
\text { s.c. }\end{array}$} & \multicolumn{5}{|c|}{$p<$} \\
\hline & & & & & $\mathrm{I} \leftrightarrow \mathrm{II}$ & $\mathrm{I} \leftrightarrow \mathrm{III}$ & $\mathbf{I} \leftrightarrow \mathrm{IV}$ & $\mathrm{II} \leftrightarrow I I I$ & $\mathrm{II} \leftrightarrow \mathrm{IV}$ \\
\hline $\begin{array}{l}\text { Arterial } \\
\text { blood glucose } \\
\mathrm{mg} / 100 \mathrm{ml}\end{array}$ & $154 \pm 5$ & $168 \pm 5$ & $168 \pm 15$ & 361 土 5 & 0.45 & 0.49 & 0.0005 & 0.5 & 0.0005 \\
\hline $\begin{array}{l}\text { Venous } \\
\text { blood glucose } \\
\mathrm{mg} / 100 \mathrm{ml}\end{array}$ & $101 \pm 3$ & $148 \pm 5$ & $140 \pm 12$ & & 0.0005 & 0.0005 & & 0.49 & \\
\hline $\begin{array}{l}\text { Suppressible } \\
\text { ILA } \\
\mu \mathrm{U} / \mathrm{ml}\end{array}$ & $416 \pm 77$ & $881 \pm 174$ & $953 \pm 268$ & $68 \pm 32$ & 0.05 & 0.05 & 0.005 & 0.5 & 0.005 \\
\hline $\begin{array}{l}\text { Immunoreactive } \\
\text { Insulin } \\
\mu \mathrm{U} / \mathrm{ml}\end{array}$ & $212 \pm 48$ & $596 \pm 54$ & $337 \pm 43$ & $106 \pm 21$ & 0.0005 & 0.005 & 0.01 & 0.005 & 0.0005 \\
\hline $\begin{array}{l}\text { Non suppressible } \\
\text { ILA } \\
\mu \mathrm{U} / \mathrm{ml}\end{array}$ & $52 \pm 17$ & $65 \pm 13$ & $51 \pm 16$ & $66 \pm 15$ & 0.49 & 0.5 & 0.49 & 0.49 & 0.5 \\
\hline$n$ & 7 & 6 & 6 & 6 & & & & & \\
\hline
\end{tabular}

samples were kept on ice until clotting occurred, then centrifuged and the serum was lyophilized and stored in sealed ampoules at $-25^{\circ} \mathrm{C}$. Before assaying for ILA the dry sera were reconstituted with water and diluted further with Krebs-Ringer bicarbonate buffer. suppressible ILA was far below the value expected on the basis of this correlation. The average values of immunoreactive insulin were lower than those of suppressible ILA. The correlation between the individual values of suppressible and immunoreactive insulin was 
rather poor. Whereas the values of suppressible ILA in both groups of rats treated with glucose were similar, immunoreactive insulin was significantly higher after subcutaneous than after oral glucose administration.

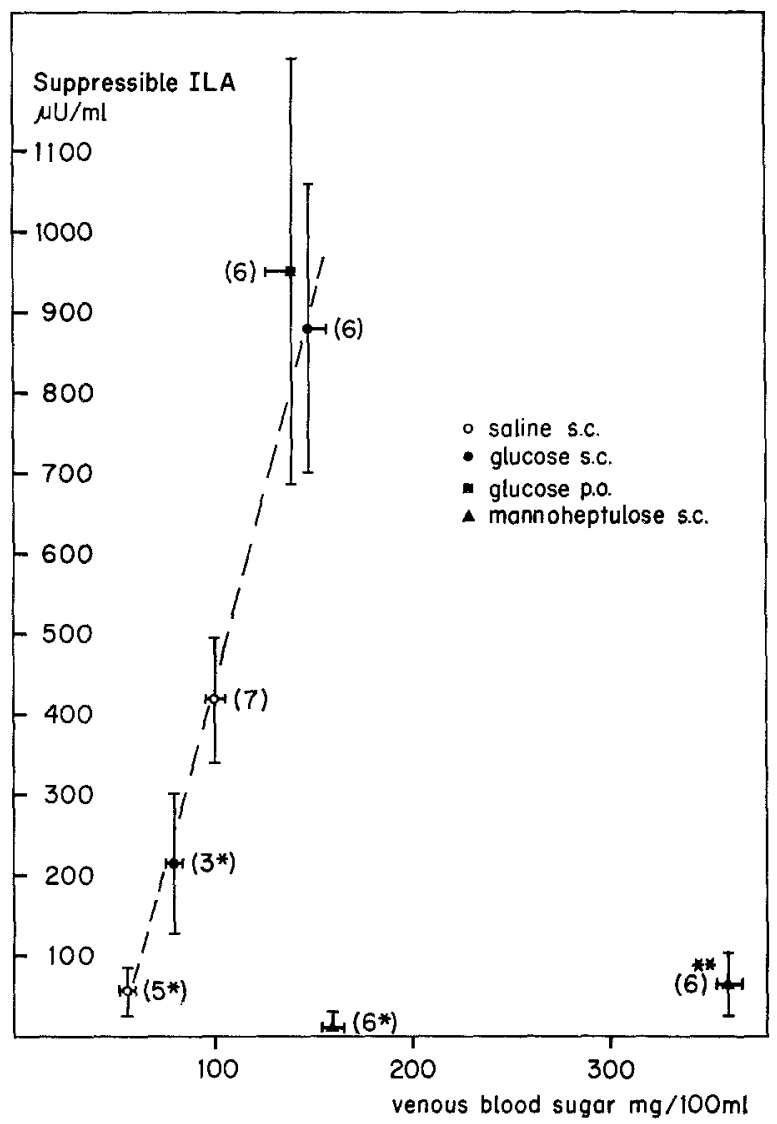

Fig. 1. Correlation of blood sugar and suppressible serum ILA in rats treated with saline, gIucose and mannoheptulose respectively

Experimental conditions are given under Materials and Methods. The means and the SEM are indicated.

* Results of the first series of rats,

** Arterial blood glucose

\section{Discussion}

The results demonstrate that mannoheptulose induces hyperglycaemia by inhibiting insulin release from the $\beta$-islet cells. Since suppressible ILA and immuno-reactive insulin were lower in the mannoheptulose groups than in the control rats, it would seem that mannoheptulose supresses not only pancreatic response to hyperglycaemia [3] but also basal insulin secretion.

There was a linear correlation between the venous blood sugar and the level of suppressible ILA in all but the mannoheptulose-treated rats. There was no apparent difference in the levels of suppressible ILA after s.e. and oral glucose administration.

In one of the two groups of rats receiving mannoheptulose the arterial blood sugar rose to $361 \mathrm{mg} /$
$100 \mathrm{ml}$ within 1 hour. This demonstrates once more how rapidly glucose homeostasis is upset when insulin secretion ceases. Two rats with arterial blood sugar concentrations of 364 and $350 \mathrm{mg} / 100 \mathrm{ml}$ had significant quantities of suppressible ILA, i.e. 193 and 140 $\mu \mathrm{U} / \mathrm{ml}$ respectively, while the other 4 had less than $30 \mu \mathrm{U} / \mathrm{ml}$. An earlier study of KRAICER, SIMON and SHELESNYAK [7] on the effectiveness of various doses of mannoheptulose had shown that the maximum hyperglycaemic response to a single dose of $400 \mathrm{mg}$ mannoheptulose was between 1 and 2 hours. Perhaps insulin secretion in these two rats had escaped mannoheptulose inhibition already one hour after manno. heptulose injection.

These relatively high values of suppressible ILA in the presence of hyperglycaemia are of particular interest with regard to the prevailing discussion about the insulin levels in human diabetes. Insulin levels in diabetes are sometimes found to be higher than in normal subjects [6]; this does not necessarily imply antagonism towards insulin or insulin unresponsiveness of the tissues as the primary causes of the exhaustion of the $\beta$-islet cells in human diabetes. It may simply reflect the extreme rapidity with which changes in the rate of insulin secretion affect glucose metabolism in the normal subject. When insulin secretion is switched off for a given period by mannoheptulose, or when it is delayed as in human diabetes [14], much time and extra insulin may be required to bring glucose homeostasis back into balance. It would be of great interest to quantitatively study the amount of extra insulin needed by mannoheptulose-treated, hyperglycaemic rats to get back to normoglycaemia.

SöNKSEN found a good correlation between immunoreactive insulin and suppressible ILA in human serum [13]. The lack of a correlation in this study may well be due to methodological difficulties related to the very high concentrations of suppressible ILA in these sera necessitating unusual serum dilutions for the bioassay. In any case, the results obtained with both methods indicate that glucose stimulates the release of a biologically and immunochemically active insulin-like material and that mannoheptulose has a contrary effect.

The question whether or not nonsuppressible ILA of serum is chemically related to insulin has not yet been resolved. SamaAn et al. found low levels of nonsuppressible ILA under circumstances of insulin deficiency such as in juvenile ketotic diabetics [9], and in pancreatectomized dogs [10]. Contrary to this we have found normal levels of nonsuppressible ILA in diabetics and even in diabetic ketosis $[4,1]$. The purification of a molecule with nonsuppressible ILA from serum yielded a molecule with a molecular weight of 6-10000 containing neither B- nor A-chain but exhibiting all the biological properties of insulin $[2,5]$.

The results presented here support our view that suppressible and nonsuppressible ILA, the effects of which on tissues in vitro are indistinguishable $[4,1]$, 
probably are not related to each other chemically and physiologically. Nonsuppressible ILA as present in serum seems to be unavailable for the tissues; otherwise, the persistance in serum after mannoheptulose administration would prevent hyperglycaemia. The purified molecule with nonsuppressible ILA is, in contrast to native nonsuppressible ILA, an effective hypoglycaemic agent [5]. The different availability of these proteins for the tissues in vivo may be related to the different permeation into the interstitial fluid.

Acknowledgements. We (E.R.F. and A.J.) wish to thank Miss Ch. Amark, S. Diem, V. SturzenegGer and M. WALDVoget for their expert technical assistance. The continued encouragement and financial support by Eli Lilly and Co. is gratefully acknowledged.

I (E.S.) am pleased to express my gratitude to $\mathrm{Mr}$. Albert Almoznino for his excellent technical assistance.

\section{References}

[1] Buergi, H., E.R. Frofisch und A. Labhart: Insulinaktivität im Blut von Patienten. Praxis 6, 181 184 (1964).

[2] --, W.A. Muelder, R. E. Humbet, A. Labhart and E.R. Froesch: Nonsuppressible insulin-like activity of human serum. I. Physiochemical properties, extraction and partial purification. Biochim. biophys. Acta, 121, 349-359 (1966)

[3] Coore, H. G., P.J. Randle, E. Simon, P. F. Kraicer and M.C. SHELesNyAK: Block of insulin secretion from the pancreas by D-mannoheptulose. Nature 197, $1264-1266(1963)$.

[4] Froesch, E.R., H. Buergi, E.B. Ramseier, P. BaLLY and A. LABHART: Antibody-suppressible and nonsuppressible insulin-like activities in human serum and their physiologic significance. An insulin assay with adipose tissue of increased precision and specificity. J. clin. Invest. 42, 1816-1834 (1963).
[5] $\rightarrow$, W.A. Muerter, H. Buergi, M. Waldvoged and A. LABHART: Nonsuppressible insulin-like activity of human serum. II. Biological properties of plasma extracts with non-suppresible insulin-like activity. Biochim. biophys. Acta, 121, 360-374 (1966)

[6] Hales, C.N., J.B. Walker, P.B. Garland and P.J• RANDLE: Fasting plasma concentrations of insulin, non-esterified fatty acids, glycerol and glucose in the early detection of diabetes mellitus. Lancet $\mathbf{1 9 6 5} \mathbf{I}$, $65-67$.

[7] Kraicer, P.F., E. Simon and M.C. Shelesnyak: Physiologic response to D-Mannoheptulose: Dose response relationships. Endocrinology 71, 90-93 (1962).

[8] RaABo, E., and T.C. Terkiddsen: On the enzymatic determination of blood glucose. Scand. J. clin. Lab. Invest. 12, 402-407 (1960).

[9] Samaan, N.A., and R. Fraser : Typical and atypical serum insulin-like activity in untreated diabetes mellitus. Lancet $1963 \mathrm{II}, 311-314$.

[10] - - , and W.J. Dempster. The typical and atypical forms of serum insulin. Diabetes 12, 339-348 (1963).

[11] Simon, E., and P.F. Kraicer: Metabolism of Mannoheptulose in the Rat. I. Diabetogenic Action. Arch. Biochem. 69, 592-601 (1957).

[12] -, R.O. Scow and S.S. Chernick: Effects of D. mannoheptulose and D-sedoheptulose on blood glucose and ketone bodies in the rat. Amer. J. Physiol. 201, 1073-1077 (1961).

[13] Sönksen, P.H., J.P. Elujs, C. Lowy, A. RutherFORD and J.D.N. NABARRo: Plasma Insulin : a corre lation between bioassay and immunoassay. Brit. med. J. 1965 II, $209-210$.

[14] YALOW, S., and S.A. BERsoN: Plasma insulin concentrations in nondiabetic and early diabetic subjectis. Diabetes 9, 254-260 (1960).

[15] ZAHND, G., and A. Luyckx: In preparation.

\author{
E.R. Froesch \\ Kantonsspital Zürich \\ Med. Universitätsklinik \\ Zürich, Schweiz
}

